\title{
Pemeriksaan Kekeruhan Air Ketuban
}

\author{
M. Sholeh Kosim \\ Bagian Ilmu Kesehatan FK UNDIP/ RSUP Dr.Kariadi Semarang
}

\begin{abstract}
Air ketuban (AK) adalah cairan jernih dengan warna agak kekuningan yang menyelimuti janin di dalam rahim selama masa kehamilan, berada di dalam kantong ketuban, dan mempunyai banyak fungsi. Air ketuban yang berubah menjadi berwarna kehijauan atau kecoklatan, menunjukkan bahwa neonatus telah mengeluarkan mekonium, menjadi petanda bahwa neonatus dalam keadaan stress dan hipoksia. menyebabkan peristaltik usus dan otot sfinter ani relaksasi sehingga mekonium dapat keluar melalui anus. Mekonium merupakan feses pertama janin dan neonatus yang juga mengandung enzim pankreas, asam lemak bebas, orfirin, interleukin-8, fosfolipase A2, biliribun indirek, dan bilirubin direk. Air merupakan komponen terbesar (85\%-95\%), sehingga kekeruhan AK sebagian besar disebabkan oleh mekonium yang mengandung feses dan asam empedu. Sehubungan keadaan tersebut maka perlu dideteksi adanya feses di dalam AK. Pemeriksaan kekeruhan dapat dilakukan secara visual (makroskopik) atau dengan mikrometer dan spektrofotometri. Berbagai penelitian mencoba menjawab pertanyaan ini. Di antaranya adalah pemeriksaan spektrofotometri, "meconium crit", dan "mecometer "Pemeriksaan feses dapat dilakukan secara konvensional dengan menggunakan uristiks yang lebih praktis untuk memeriksa komponen kimiawi, untuk berbagai macam tujuan. (Sari Pediatri 2010;11(5):379-84).
\end{abstract}

Kata kunci: kekeruhan air ketuban, meconium crit, mecomete

$\mathrm{J}$ anin di dalam rahim laksana mengambang di dalam air ketuban (selanjutnya disebut AK). Selama kehamilan volume AK meningkat sesuai dengan pertumbuhan janin.

Volume paling besar terjadi saat mendekati umur kehamilan 34 minggu, dengan rerata volume 800 mililiter. Kurang lebih 600 mililiter AK meliputi janin saat neonatus cukup bulan (40 minggu kehamilan) dan saat dilahirkan. Cairan AK bersirkulasi dengan

\footnotetext{
Alamat korespondensi:

Dr. M. Sholeh Kosim, SpA(K). Sub Bagian Perinatologi Bagian IKA FK UNDIP/RSUP Dr.Kariadi Semarang, E-mail : mskosim@indosat.net.id
}

cara janin menelan dan menghirup serta pengeluaran melalui urin janin. ${ }^{1}$ Air ketuban yang normal jernih berwarna agak kekuningan, menyelimuti janin di dalam rahim selama masa kehamilan. Air ketuban berada di dalam kantong ketuban, mempunyai berbagai fungsi antara lain,

a. Memungkinkan janin untuk bergerak bebas dan perkembangan muskuloskeletal,

b. Memelihara janin dalam lingkungan suhu yang relatif stabil, yang meliputi janin sehingga melindungi janin dari kehilangan panas,

c. Memungkinkan perkembangan paru janin, ${ }^{2}$

d. Sebagai bantalan dan melindungi janin. Saat trimester kedua, janin mampu menghirup cairan ke 
dalam paru dan menelannya, sehingga mendorong perkembangan dan pertumbuhan normal sistem paru dan pencernaan. Janin bergerak bebas dalam AK sehingga membantu perkembangan otot dan tulang. Kantung ketuban terbentuk saat duabelas hari setelah pembuahan, kemudian segera terisi oleh AK. Saat minggu-minggu awal kehamilan, AK terutama mengandung air yang berasal dari ibu, setelah sekitar duapuluh minggu urin janin membentuk sebagian besar AK

e. Mengandung nutrien, hormon dan antibodi yang melindungi dari penyakit. ${ }^{3}$

f. Air ketuban berkembang dan mengisi kantong ketuban mulai dua minggu sesudah pembuahan. Setelah sepuluh minggu kemudian AK mengandung protein, karbohidrat, lemak, fosfolipid, urea, dan elektrolit, untuk membantu pertumbuhan janin. Pada saat akhir kehamilan sebagian besar AK terdiri dari urin janin. ${ }^{3}$

g. Air ketuban secara terus menerus ditelan, "dihirup" dan diganti lewat proses ekskresi seperti juga dikeluarkan sebagai urin. Merupakan hal yang penting bahwa AK dihirup ke dalam paru janin untuk membantu paru mengembang sempurna, AK yang tertelan membantu pembentukan mekonium keluar saat ketuban pecah. Apabila ketuban pecah terjadi selama proses persalinan disebut ketuban pecah spontan, apabila terjadi sebelum proses persalinan disebut sebagai ketuban pecah dini. Sebagian besar AK tetap berada dalam rahim sampai neonatus lahir. ${ }^{3}$

Warna AK kehijauan atau kecoklatan menunjukkan bahwa neonatus telah mengeluarkan mekonium (kotoran yang terbentuk sebelum lahir, pada keadaan normal keluar setelah lahir saat pergerakan usus yang pertama kali). Hal ini dapat menjadi petanda bahwa neonatus dalam keadaan stres. Keadaan hipoksia menyebabkan peristaltik usus dan relaksasi otot sfingter ani, maka mekonium dapat keluar melalui anus. ${ }^{4}$

Seorang neonatus dapat menghirup cairan tersebut sehingga mengakibatkan masalah pernapasan yang serius yaitu sindrom aspirasi mekonium (SAM) yang membutuhkan penanganan yang tepat. Apabila seorang klinikus melihat mekonium selama proses persalinan, dapat dilakukan pemberian amnioinfusion bagi ibu dengan harapan dapat mencegah berbagai komplikasi pada neonatus. Cairan yang berwarna merah jambu menunjukkan perdarahan yang baru terjadi, sedangkan AK yang berwarna seperti anggur menunjukkan adanya riwayat perdarahan. Tanda warna AK tersebut kemungkinan trivial tetapi dapat membantu menentukan penyebab yang mungkin. ${ }^{5}$

Komposisi dari air ketuban tertera pada Tabel 1.

Tabel 1 : Komposisi air ketuban normal

\begin{tabular}{lc}
\hline Kandungan & Kadar \\
\hline Kalsium $(\mathrm{mEq} / \mathrm{L})$ & 4 \\
Klorida $(\mathrm{mEq} / \mathrm{L})$ & 102 \\
CO2 $(\mathrm{mEq} / \mathrm{L})$ & 16 \\
Kreatinin $(\mathrm{mg} / \mathrm{dL})$ & 1,8 \\
Glukosa $(\mathrm{mg} / \mathrm{dL})$ & 29,8 \\
Ph & 7,04 \\
Kalium $(\mathrm{mEq} / \mathrm{L})$ & 4,9 \\
Natrium $(\mathrm{mEq} / \mathrm{L})$ & 133 \\
Total protein $(\mathrm{gram} / \mathrm{dL})$ & 2,5 \\
Albumin $(\mathrm{gram} / \mathrm{dL})$ & 1,4 \\
Urea $(\mathrm{mg} / \mathrm{dL})$ & 31 \\
Asam urat $(\mathrm{mg} / \mathrm{dL})$ & 4,9
\end{tabular}

Sumber : Williams $\mathrm{W}^{6}$

Asal AK steril namun oleh karena mekonium adalah media yang paling baik untuk bakteri tumbuh dengan subur, meskipun masih dalam perdebatan namun banyak pakar yakin bahwa mekonium dapat menyebabkan iritasi pada saluran napas. ${ }^{7}$

\section{Mekonium}

Istilah mekonium berasal dari bahasa Yunani kuno meconium-arion atau seperti opium. Aristoteles mempergunakan istilah tersebut karena dipercaya

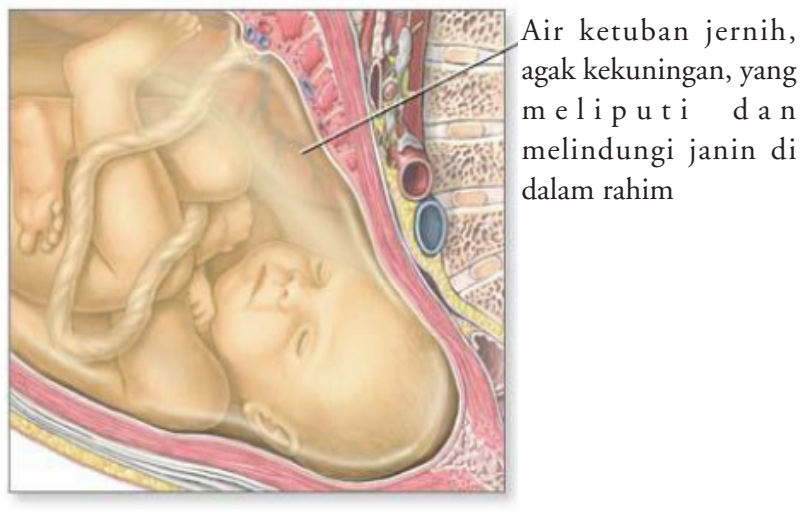

Gambar 1. Janin dan AK dalam rahim

Sumber: Medical Encyclopedia. Amniotic fluids ${ }^{8}$ 
mekoneum membuat janin tidur. Isi usus janin dan mekonium adalah campuran berbagai bahan kimia yang steril, termasuk glikoprotein mukus, verniks caseosa yang tertelan, sekresi saluran pencernaan, enzim hati, pankreas dan empedu, protein plasma, mineral, dan lipid

Mukopolisakarida menyusun $80 \%$ berat kering mekonium. Kadar enzim pankreas dan hati bervariasi sesuai usia gestasi. ${ }^{9}$ Air ketuban secara terus menerus ditelan, "dihirup" dan diganti lewat proses ekskresi seperti juga dikeluarkan sebagai urin. Merupakan hal yang penting bahwa AK dihirup ke dalam paru janin untuk membantu fungsi paru. Komposisi mekonium tertera pada Tabel 2. pusat pun akan berwarna oleh mekonium dalam waktu tiga jam dan makrofag dalam satu jam. ${ }^{7}$

\section{Cara mendeteksi kekeruhan air ketuban}

Cara mengetahui atau mendiagnosis mekonium dalam AK saat masa kehamilan dapat digunakan beberapa modalitas seperti amnioskopi transervikal, amniosintesis dan terakhir ultrasonografi serta magnetic resonance spectroscopy. Suatu penelitian guna menurunkan angka kematian perinatal dihubungkan mekonium dalam AK dengan kelainan ritme jantung. Hasil penelitian menunjukkan 56\% janin dengan mekonium dalam

Tabel 2. Komposisi mekonium janin pada neonatus cukup bulan

\begin{tabular}{ll}
\hline - Kolesterol dan prekusor sterol & - Lemak \\
- Substansi golongan darah & - Asam empedu dan garam empedu \\
- Air & - Enzim \\
- Protein & - Sel skuamosa \\
\hline
\end{tabular}

Sumber : Glantz CJ, Wood JR Jr' ${ }^{10}$

\section{Air ketuban keruh}

Mekonium adalah substansi mirip tar yang kental dan berwarna kehijauan yang berada di usus janin selama kehamilan. Secara normal AK tidak dikeluarkan dengan pergerakan usus sampai neonatus dilahirkan, dalam keadaan tertentu dapat ditemukan pergerakan usus tersebut sebelum lahir. Jika didapatkan mekonium selama proses persalinan dan kelahiran, harus diamati lebih cermat tanda gawat janin atau posisi janin letak sungsang. Adanya pewarnaan mekonium dalam AK bukan berarti neonatus mengalami gawat janin. Maka apabila ditemukan mekonium berwarna, tim penolong persalinan dan kelahiran sebaiknya mencari tanda-tanda yang lain. Mekonium yang 'encer' / cair bukan merupakan risiko atau tanda gawat janin, tapi merupakan tanda kematangan neonatus. Hal yang lebih berbahaya bagi neonatus adalah jika ditemukan mekonium saat proses persalinan sehingga harus dicari tanda-tanda gawat janin. ${ }^{11}$

Dijumpainya mekonium di dalam AK meninggalkan bekas atau sejumlah bukti. Apabila mekonium berada selama empat jam atau lebih di dalam AK, maka dasar kuku (nail bed) janin akan berwarna dan kalau berada di dalam AK duapuluh empat jam atau lebih verniks kaseosa akan ikut berwarna. Selaput ketuban dan tali
AK berat, 22\% janin dengan mekonium dalam AK ringan, atau AK jernih, mempunyai ritme jantung yang abnormal. Ternyata pula total kematian perinatal pada semua janin dengan mekonium dalam AK dan semua janin dengan abnormalitas ritme jantung hanya 3\%. Berhubung terdapat kelemahan dalam tiap modalitas tersebut, maka deteksi mekonium dalam AK dan makna mekonium dalam sebagai faktor gawat janin tidak begitu kuat. Oleh karena itu upaya mendiagnosis mekonium dalam AK saja dalam masa kehamilan tidak banyak dikerjakan lagi karena kurang bermanfaat. ${ }^{7}$

\section{Penilaian air ketuban keruh}

Beberapa penelitian telah dilakukan untuk mengetahui mekonium di dalam air ketuban karena mortalitas dan morbiditas sindrom aspirasi mekonium (SAM) yang tinggi. Penilaian secara kualitatif yaitu dengan melihat kekeruhan air ketuban secara visual, dapat dibedakan air ketuban antara thick, medium, dan thin, kelemahan penilaian secara visual bersifat subjektif dari penilai. ${ }^{12}$

Air ketuban keruh bercampur mekonium (selanjutnya disebut AKK) merupakan faktor risiko berbagai masalah perinatal. Bayi dengan AKK kental 
lebih sering mempunyai masalah yang lebih besar dibanding bayi dengan AKK yang encer. Secara umum kandungan mekonium di dalam AK dikelompokkan ke dalam tiga kategori yaitu encer, sedang, dan kental. Penilaian kandungan mekonium tergantung sepenuhnya pada pengamatan subjektif para klinisi. Meskipun penilaian subjektif tidak menimbulkan masalah serius, banyak penelitian dilakukan untuk menilai mekonium secara objektif. Di antaranya pemeriksaan spektrofotometri dan meconium crit, pemeriksaan yang sederhana dan dapat dipercaya, namun alat tidak mudah dibawa atau dipindahkan sehingga agak menyulitkan para klinisi. ${ }^{13}$ Pada kenyataannya alat tersebut tidak digunakan secara rutin dalam praktik sehari hari. Park dan Shin ${ }^{11}$ di Korea melakukan penilitian dengan alat sederhana dan portabel untuk menilai kandungan mekonium secara objektif dan telah dilakukan verifikasi untuk objektivitas dan reliabilitasnya, disebut mecometer ${ }^{14}$ (Gambar 2).

Sanlialp $\mathrm{dkk}^{12}$ meneliti keakuratan penilaian air ketuban keruh bercampur mekonium secara visual dibandingkan dengan pemeriksaan spektofotometri, menunjukkan bahwa penilaian secara visual sama dengan penilaian spektofotometri (accuracy rate $=$ $54,74 \%, p<0,001)$. Sedangkan penelitian penilaian AKK secara in vitro dengan mengukur konsentrasi mekonium dengan cara menggunakan tabung hematokrit yang disentrifugasi, dinilai panjang endapan yang menunjukkan nilai meconium-crit secara linear berhubungan dengan konsentrasi mekonium dalam air ketuban $(r=0,901-0,995) .{ }^{13}$

Upaya untuk mengetahui adanya mekonium dalam AK dapat dilakukan pada waktu ketuban sudah pecah saat kehamilan atau setelah neonatus lahir. Mengetahui kekeruhan AK sangatlah subjektif karena

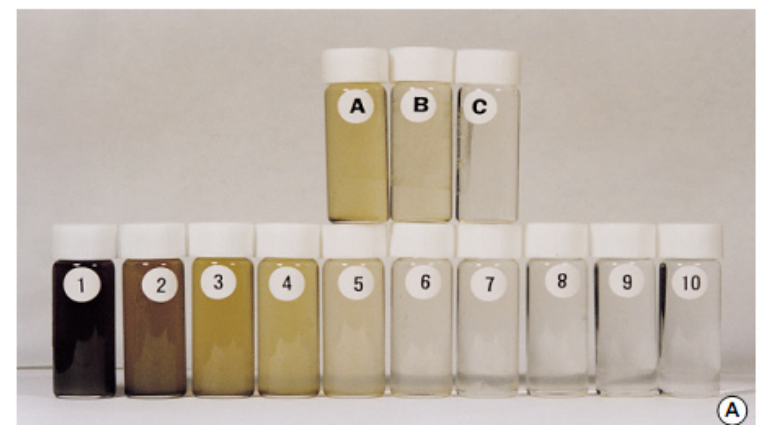

Gambar 2: Mekometer $^{14}$ sangat bervariasi dari satu kehamilan ke kehamilan lain. Disebutkan bahwa AK secara terus menerus ditelan, 'dihirup,' dan diganti lewat proses menghembuskan, dan juga dikeluarkan sebagai urin. ${ }^{2}$

\section{Deteksi feses dalam air ketuban keruh}

Mekonium merupakan feses pertama janin dan neonatus yang juga mengandung enzim pankreas, asam lemak bebas, orfirin, interleukin-8, dan fosfolipase A2, biliribun indirek, bilirubin direk dan air merupakan komponen terbesar (85\%-95\%) dari mekonium. ${ }^{15}$ Sehubungan masalah yang telah diterangkan, maka perlu kiranya mendeteksi adanya feses di dalam AKK.

\section{Pemeriksaan feses secara konvensional}

Pemeriksaaan secara konvensional dapat dilakukan antara lain dengan memeriksa adanya salah satu metabolit bilirubin atau sterkobilin. Dalam keadaan normal dua pertiga tinja terdiri dari air dan sisa makanan, zat hasil sekresi saluran pencernaan, epitel usus, bakteri a-patogen, asam lemak, urobilin, gas indol, skatol dan sterkobilinogen. Warna tinja normal kuning coklat, dapat berubah menjadi lebih tua karena urobilin terbentuk lebih banyak. Selain oleh urobilin, warna tinja dipengaruhi oleh berbagai jenis makanan, kelainan dalam saluran cerna, dan obat yang dimakan. ${ }^{16.17}$

Bahan pemeriksaan tinja sebaiknya didapat dari defekasi spontan, jika pemeriksaan sangat diperlukan contoh tinja dapat diambil dengan cara colok dubur. Untuk pemeriksaan rutin dipakai tinja sewaktu dan sebaiknya tinja diperiksa dalam keadaan segar karena bila dibiarkan mungkin sekali unsur unsur dalam tinja menjadi rusak

\section{Pemeriksaan makroskopik}

Pemeriksaan makroskopik tinja meliputi pemeriksaan jumlah, warna, bau, darah, lendir, dan parasit. Dalam keadaan normal jumlah tinja berkisar antara 100-250 gram per hari. Banyaknya tinja dipengaruhi jenis makanan bila banyak makan sayur jumlah tinja meningkat. Tinja normal mempunyai konsistensi agak lunak dan berbentuk. Pada diare konsistensi 
menjadi sangat lunak atau cair, sedangkan sebaliknya tinja yang keras atau skibala didapatkan pada konstipasi. Peragian karbohidrat dalam usus menghasilkan tinja yang lunak dan bercampur gas. Warna tinja normal kuning coklat, dapat berubah menjadi lebih tua dengan terbentuknya lebih banyak urobilin. Selain urobilin warna tinja dipengaruhi oleh berbagai jenis makanan, kelainan dalam saluran cerna, dan obat yang dimakan. Warna kuning dapat disebabkan karena susu, jagung, lemak, dan obat santonin. Tinja yang berwarna hijau dapat disebabkan oleh sayuran yang mengandung klorofil atau pada neonatus yang baru lahir disebabkan oleh biliverdin dan porfirin dalam mekonium. Warna kelabu mungkin disebabkan karena tidak ada urobilinogen dalam saluran cerna, terdapat pada ikterus obstruktif disebut tinja akholis. Dalam tinja normal selalu ada urobilin ${ }^{17}$

\section{Pemeriksaan mikroskopik}

Pemeriksaan mikroskopik meliputi pemeriksaan protozoa, telur cacing, leukosit, eritosit, sel epitel, kristal, dan sisa makanan. Dari semua pemeriksaan mikroskopis yang terpenting adalah pemeriksaan terhadap protozoa dan telur cacing. ${ }^{16,17}$

\section{Pemeriksaan urin kimia stik atau urine strip test}

Pemeriksaan urin kimia stik banyak menggantikan pemeriksaan cara kimia konvensial karena mudah, praktis, dan murah. Walaupun demikian untuk mendapatkan hasil yang reliabel, perlu mempelajari prinsip kimiawi, proses penyimpanan reagen kering, persiapan bahan, dan cara pembacaan hasil. Hal-hal yang perlu diperhatikan adalah,

1) Reagen pita harus disimpan dalam botol asalnya, tidak boleh dipindah-pindahkan dan botol harus dalam keadaan tertutup.

2) Jangan menyentuh kolom pita reagen, hindari kontaminasi dengan deterjen dan bahan kimiawi.

3) Jangan memakai reagen pita yang sudah kadaluwarsa. ${ }^{18}$ Parameter yang dapat diperiksa dari sampel urin adalah, berat jenis, lekosit, nitrit, $\mathrm{pH}$, protein, glukosa, keton, urobilinogen, bilirubin, dan darah ${ }^{18}$

\section{Pemeriksaan urine strip test untuk pemeriksaan lain}

Penggunaan urine strip test untuk keperluan pemeriksaan di luar pemeriksaan urin, pernah dilaporkan oleh Akman dalam usaha untuk mendeteksi adanya leukosit dalam cairan dialisat peritoneal, menggunakan urine dipstick dianggap lebih praktis. Metode yang digunakan pada 44 sampel dari empat orang anak yang menderita peritonitis. Jumlah leukosit total dan neutrofil polimorfonuklear (PMN) dihitung dengan menggunakan hemositometer (CELDYN 3700 R) dan cara mikroskopis. Keberadaan leukosit diteliti dengan menggunakan tes urine dipsticik. Hasil penelitian menunjukkan bahwa urine dipstick test berhubungan dengan kedua cara pemeriksaan tersebut (hemocytometer dan cara mikroskopis) (berturut-turut $\mathrm{r}=0,537, p=0.001 ; \mathrm{r}=0,560, p=0,0001)$. Hasil ini menunjukkan tidak adanya hasil negatif palsu pada semua kategori strip test. Pada nilai potong/cut-off point (>100/mm3 leukosit) menunjukkan hasil positif (3+) pada pembacaan strip test dengan mencapai sensitivitas $100 \%$ untuk mendeteksi peritonitis dengan spesifitas $100 \%$. Hasil positif (2+) pada pembacaan hasil strip test mencapai sensitivitas $100 \%$ dengan spesifitas yang lebih rendah $(71,4 \%)$ pada cut-off yang sama. Hasil dipstick test berhubungan secara signifikan dengan jumlah total PMN ( $\mathrm{r}=0.80, p=0,0001)$. Seluruh kategori strip test positif mendapat hasil lebih dari 50\% PMN dengan prosentase rendah pada hasil kategori negatif pada sampel cairan dialisis peritoneal. Kesimpulan strip test berguna untuk mendiagnosis peritonitis bakterialis dengan mendeteksi sel leukosit dan PMN pada cairan dialisis peritoneal. ${ }^{15}$

Penggunaan uristik yang lain untuk mengevaluasi kecepatan diagnosis guna memprediksi adanya infeksi saluran kemih saat kehamilan. Standar baku emas yang digunakan adalah pemeriksaan mikroskopis, kultur, dan uji sensitivitas. Dibandingkan uristik yang menggunakan leukosit esterase, nitrit, dan protein tunggal maupun ganda menghasilkan komponen leukosit esterase mempunyai reliabilitas dan validitas yang tinggi. ${ }^{19}$

\section{Ringkasan}

Dalam keadaan normal air ketuban merupakan cairan jernih dengan warna agak kekuningan yang menyelimuti janin di dalam rahim selama masa kehamilan, berada di 
dalam kantong ketuban, dan mempunyai banyak fungsi. Selama proses kehamilan AK dapat berubah menjadi keruh dan berwarna kehijauan atau kecoklatan yang menunjukkan bahwa neonatus telah mengeluarkan mekonium dan menjadi petanda bahwa neonatus dalam keadaan stress dan hipoksia.

Menentukan kekeruhan AK berdasarkan pengamatan visual para klinisi kadang sangat subjektif maka dilakukan beberapa penelitian terhadap pemeriksaan spektrofotometri, "meconium crit", dan "mecometer". Hal penting adalah memeriksa kandungan AK yang mengandung mekonium dengan komponen paling besar adalah feses dan asam empedu. Pemeriksaan feses dapat dilakukan secara konvensional dan menggunakan uristiks.

\section{Daftar Pustaka}

1 University of Maryland. Amniotic fluids. Diunduh Mei 2008. dari URL http://www.umm.edu/ency/article/002220. htm, Anonymous Amniotic Fluid. Diunduh dari URL : http:/len.wikipedia.org/wiki/Amniotic_fluid.

2. Anonymous. Amniotic Fluid. Diunduh Mei 2008. dari URL: http://en.wikipedia.org/wiki/Amniotic_fluid

3. Amniotic Fluid Abnormalities - March of Dimes . Diunduh Mei 2008 dari URL: http://www.marchofdimes. com/professionals/14332_4536.asp

4. Ahanya SN, Lakshmanan J, Morgan BL, Ross MG. Meconium passage in utero: mechanisms, consequences, and management. Obstet Gynecol Surv 2005;60:45-56.

5. Korourian S, De Las Casas L. Normal and abnormal placentation.. Dalam: Clinical Obstetrics, The fetus and mother, Reece EA, Hobbins JC, Gant NF Jr, penyunting. Edisi ketiga, Blackwell, Oxford; 2007.h.35-7.

6. Williams W. Amniotic Fluid : objectives with narration and illustrations. Diunduh Mei 2008 dari URL: http// www. CLS-1521

7. ChalikTMA. Mekonium dalam cairan ketuban. Dalam: Ilmu Kedokteran Fetomaternal. Hariadi R, penyunting. Edisi perdana. Himpunan Kedokteran Fetomaternal. Surabaya: POGI; 2004.h.413-8.
8. Medical Encyclopedia. Amniotic fluids.Diunduh Mei 2008. dari URL: http://www.nlm.nih.gov/medlineplus/ency/ imagepages $/ 17008$. htm

9. HON Mother \& Child Glossary. Meconium . Diunduh Mei 2008. dari URL: http://www.hon.ch/Dossier/MotherChild/ labor_complications/birt

10. Glantz CJ, Wood JR Jr. Significance of amniotic fluid meconium. Dalam: Maternal-fetal medicine. Creasy RK, Resnik R, Iams JD, penyunting. Edisi ke-5, Sanders, USA; 2002.h.441-8.

11. Weiss RE. Meconium. Diunduh Juni 2008 dari URL: http://pregnancy.about.com/od/laborcomplications/almeconium. htm

12. Sanlialp C, Caglar GS, Tapisiz OL, Avsar AF. An assesment of the accuracy of visual diagnosis of meconium-stained amniotic fluid. Pak J Med Scil 2004:20;137-40.

13. Akman S, Uygun V,; Guven Ag. Value of the urine strip test in the early diagnosis of bacterial peritonitis . Diunduh dari URL: Diunduh Agustus 2008. http://cat. inist. frl?aModele $=$ afficheNerpsidt $=17207999$

14. Park SK, Shin SH. Newly developed mecometer method for objective assessment of meconium content . J Korean Med Sci 2002;17:15-7.

15. Akman S, Uygun V, Guven Ag, Value of the urine strip test in the early diagnosis of bacterial peritonitis. Diunduh dari URL : http://cat.inist.frl?aModele=afficheNospsidt $=$ 17207999

16. Immanuel S, Dharma R, Wirawan R . Penilaian hasil pemeriksaan tinja. Diunduh Maret 2009 dari URL: http:// www.kalbe.co.id/files/cdk/files/11_PenilaianHasilPemeriksaan

17. Gandasoebrata R. Penuntun laboratorium klinik. Cetakan ke-14. Jakarta. Dian Rakyat, 2008.

18. Boentoro D. Pemeriksaan urin kimia stix. Dalam: Pemeriksaan laboratorium ginjal dan saluran kemih (konsep penafsiran dan S O P). Malang: Fakultas Kedokteran Universitas Brawijaya, RSUD Dr. Saiful Anwar, 2007.h.14-7.

19. Eigbefoh J, Isabu P, Okpere E, Abebe J. The diagnostic accuracy of the rapid dipstick test to predict asymptomatic urinary tract infection of pregnancy. J Obstet Gynaecol 2008;28:490. 